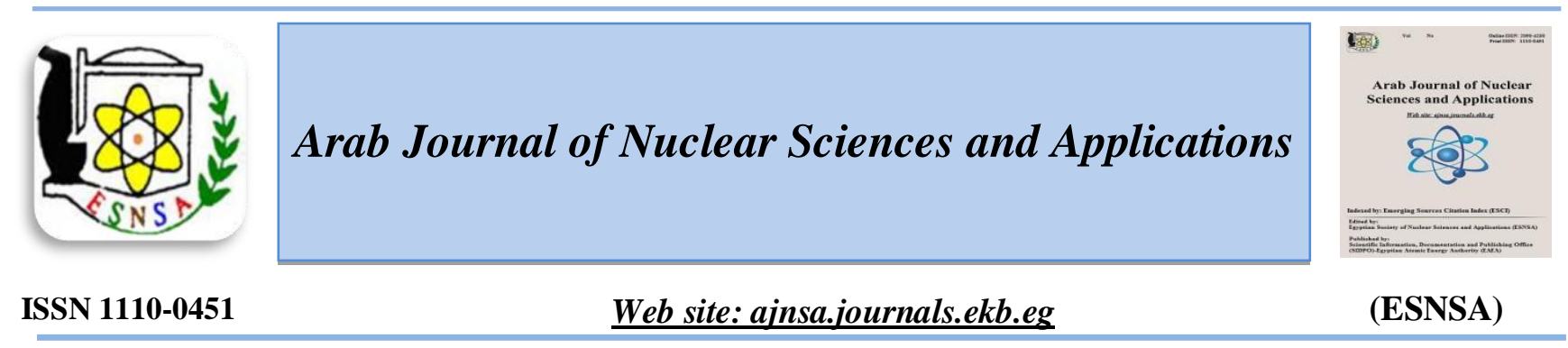

\title{
Effects of Zn and Sb Additions on Microstructure, Creep Behavior and Thermal Properties of Binary Eutectic Sn-0.7\% Cu Lead-Free Solder
}

\author{
A.M. Yassin \\ Physics Department, Faculty of Education, Ain shams university, Cairo, Egypt
}

Received $16^{\text {th }}$ July 2018 The effects of $\mathrm{Zn}$ and $\mathrm{Sb}$ additions on microstructure, creep behavior and thermal properties of binary Accepted 31 ${ }^{\text {st }}$ March eutectic Sn-0.7\% Cu lead-free solder were investigated. Results show that $\mathrm{Zn}$-addition reduced the 2019

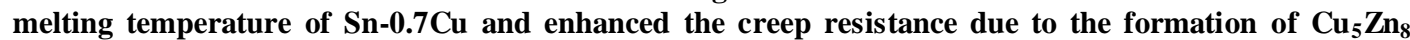
intermetallic compound (IMC) and reduction of $\mathrm{Cu}_{6} \mathrm{Sn}_{5}$ phase in $\beta$-Sn matrix. Conversely, the $\mathrm{Sb}$ addition showed a negative effect on both the creep resistance and melting temperature compared to the plain $\mathrm{Sn-0.7} \mathrm{Cu}$ and $\mathrm{Sn-0.7} \mathrm{Cu}-2.0 \mathrm{Zn}$ alloys due to the formation of SnSb IMC particles and coarse $\mathrm{Cu}_{6} \mathrm{Sn}_{5}$ phase through the $\beta$-Sn rich phase. The average stress exponents of 4.9-6.0 and activation energies of 50-60 KJ/mol were obtained for three solders; suggesting that the dislocation climb controlled by lattice diffusion is the dominant creep mechanism. X-ray diffraction (XRD) analysis revealed that the lattice parameters (a), (c), the axial rate (c/a) and the peak height intensities (hkl) of some crystallographic planes are changed with alloying additions and the crystallite size is decreased.

Keywords: Pb-free solders, Thermal properties, Microstructure, Alloying element additions, creep, X-ray analysis

\section{Introduction}

Recently, a lot of efforts have been made to replace the conventionally used $\mathrm{SnPb}$ solders by new $\mathrm{Pb}$-free alloys due to the considerable toxicity of lead $(\mathrm{Pb})$ on health and environment. The $\mathrm{Sn}-\mathrm{Cu}$ based alloys are one of the families of promising $\mathrm{Pb}$-free candidates due to their low cost and good mechanical properties and electrical conductivity. Nevertheless, the eutectic $\mathrm{Sn}-0.7 \mathrm{Cu}$ has a high melting temperature of $227^{\circ} \mathrm{C}$, which is still a problem of $\mathrm{Sn}-\mathrm{Cu}$ alloys [1]. Improving the physical properties of $\mathrm{Pb}$-free alloys has been obtained by modification of chemical composition and addition of minor elements as well as the development of new processing routes by means of rapid solidification and mechanical alloying [2].Huang et.al studied the creep properties of three precipitation-strengthened $\mathrm{Sn}$-based $\mathrm{Pb}$-free solder alloys $(\mathrm{Sn}-0.7 \mathrm{Cu}, \mathrm{Sn}-3.5 \mathrm{Ag}$ and $\mathrm{Sn}-$ $3.8 \mathrm{Ag} 0.7 \mathrm{Cu}$ ) at constant applied stress of 17.5 $\mathrm{MPa}$ and working temperature of $348 \mathrm{~K}$. They found that $\mathrm{Sn}-0.7 \mathrm{Cu}$ has the lowest creep resistance compared with the other two alloys [3]. The creep behavior of $\mathrm{Sn}-0.7 \mathrm{Cu}$ alloy with small amounts of inter-metallic compound (IMCs) of $\mathrm{Cu}_{6} \mathrm{Sn}_{5}$ particles in the $\square$-Sn matrix has been studied by $\mathrm{Wu}$ and Huang [4]. They indicated that the creep rates are controlled by the dislocation pipe diffusion in Sn matrix. Microstructure studies at different cooling rates on different compositions of $\mathrm{Sn}-\mathrm{Cu}$ alloys $(\mathrm{Sn}-0.5 \mathrm{wt} \% \mathrm{Cu}, \mathrm{Sn}-0.7 \mathrm{wt} \% \mathrm{Cu}$, $\mathrm{Sn}-0.9$ wt. \% Cu) showed that the $\mathrm{Sn}-\mathrm{Cu}$ system is a weakly irregular eutectic system due to the formation of $\mathrm{Cu}_{6} \mathrm{Sn}_{5}$ IMCs with two different

Corresponding author: amalyassin@hotmail.com

DOI: 10.21608/ajnsa.2019.4450.1103

(C) Scientific Information, Documentation and Publishing Office (SIDPO)-EAEA 
eutectic morphologies (coarse and fine) during eutectic growth [5]. The indentation creep tests of $\mathrm{Sn}-\mathrm{Cu}$ alloys $(1-5 \mathrm{wt} . \% \mathrm{Cu})$ has been investigated and concluded that the composition of Sn-4wt. \% $\mathrm{Cu}$ solder alloy exhibited the greatest creep resistance [6]. The addition of In element enhanced the indentation creep of $\mathrm{Sn}-0.7$ wt. \% $\mathrm{Cu}$ solders [7]. The improvement of wettability, mechanical characteristics and creep resistance $\mathrm{Sn}-\mathrm{Cu}$ alloys by introduction of a small amount of alloying elements were proposed by many researchers [89]. The addition of $0.5 \%$ rare earth elements (REE) to the $\mathrm{Sn}-0.7 \% \mathrm{Cu}$ binary alloy improves the microstructures and refines both the $\beta$-Sn grains and the $\mathrm{Cu}_{6} \mathrm{Sn}_{5}$ IMCs in addition to their attractive mechanical properties (hardness, and creep resistance) [8]. Adding of $\mathrm{Ag}$ or In-element to Sn$0.7 \mathrm{Cu}$ solder decreased the melting temperature $\left(T_{\mathrm{m}}\right)$ from $227^{\circ} \mathrm{C}$ to $224^{\circ} \mathrm{C}$ and $217^{\circ} \mathrm{C}$, respectively and increased the creep resistance compared to the plain alloy [10-12]. Alam et.al studied the effect of adding $(2,2.5$ and 4.5$)$ wt. \% $\mathrm{Ag}$ to $\mathrm{Sn}-0.7 \mathrm{Cu}$ eutectic alloy on the microstructure, mechanical properties (hardness) and thermal properties. They found reduction in melting temperature from $234.88{ }^{\circ} \mathrm{C}$ to $226.89{ }^{\circ} \mathrm{C}$ and increasing in the hardness, while by adding $\mathrm{Ag}$ up to $2.5 \mathrm{wt} . \%$ the hardness was decreased [13]. Also, the addition of $\mathrm{Ni}, \mathrm{Co}, \mathrm{Ga}, \mathrm{In}, \mathrm{Bi}$ or rare earth elements into Sn$0.7 \mathrm{Cu}$ solder showed improvement of hardness [14]. Ning Zhao et. al [15] indicated that after doping $\mathrm{Ce}$ element in $\mathrm{Sn}-0.7 \mathrm{Cu}$ solder, the melting temperature was increased although the wettability was improved. The effect 0.08 wt.\% Ni-addition on the microstructure and the mechanical properties of $\mathrm{Sn}-0.7 \mathrm{Cu}$ alloy has been studied by Gyenes et. al [16]. They found that $\mathrm{Sn}$ $0.7 \mathrm{Cu}-\mathrm{Ni}$ alloy becomes fully eutectic $[\beta-\mathrm{Sn}+$ $\left.(\mathrm{Cu}, \mathrm{Ni})_{6} \mathrm{Sn}_{5}\right]$, and the ultimate tensile strength (UTS), yield strength (YS) and hardness (HV) were increased. However, above a certain level of additions, their values were decreased whereas, the elongation was significantly increased with the appearance of large primary $(\mathrm{Cu}, \mathrm{Ni})_{6} \mathrm{Sn}_{5}$ (IMCs). Taruk et. al [17] showed that the addition of $0.5 \mathrm{wt} . \% \mathrm{Zn}$ to the $\mathrm{Sn}-\mathrm{Cu}$ eutectic alloy increases the hardness and YS, but slightly lowers the creep resistance. They also found that the addition of $\mathrm{Bi}$ decreases both the creep resistance and fracture time. In general, the effect of the primary phase $\left(\mathrm{Cu}_{6} \mathrm{Sn}_{5}\right)$ on the creep behavior of Sn-rich is very essential in designing better solder alloy and in understanding the deformation mechanism. However, there is seldom systematic data on the effect of $\mathrm{Zn}$ or/ and $\mathrm{Sb}$ additions on eutectic $\mathrm{Sn}-\mathrm{Cu}$ solder alloys. In this research, $2.0 \mathrm{wt} . \% \mathrm{Zn}$ and $\mathrm{Sb}$ were added into $\mathrm{Sn}-0.7 \mathrm{Cu}$ alloys. In order to obtain $\mathrm{Sn}-0.7 \mathrm{Cu}$ solder with good creep resistance, the microstructures and creep properties were studied and discussed in this paper to confirm the requirements of performance, melting temperature and pasty range were also discussed.

\section{Experimental Work}

Three solder alloys of compositions Sn$0.7 \mathrm{wt} . \% \mathrm{Cu}, \mathrm{Sn}-0.7 \mathrm{wt} . \% \mathrm{Cu}-2 \mathrm{wt} . \% \mathrm{Zn}$ and $\mathrm{Sn}-0.7$ wt.\% Cu-2 wt.\% Sb were prepared form high purity (99.99 wt\%) component materials. The chemical compositions of three alloys are given in Table (1).

Table (1): Chemical compositions of the studied solders (wt.\%)

\begin{tabular}{lcccc}
\hline Alloy & $\mathrm{Cu}$ & $\mathrm{Sb}$ & $\mathrm{Zn}$ & $\mathrm{Sn}$ \\
\hline Sn-0.7Cu & 0.7 & - & - & Bal. \\
Sn-0.7Cu -2Sb & 0.7 & 2.0 & - & Bal. \\
Sn-0.7Cu -2Zn & 0.7 & - & 2.0 & Bal. \\
\hline
\end{tabular}

To ensure the dissolution of $\mathrm{Sn}, \mathrm{Cu}$ and $\mathrm{Sb}$ or $\mathrm{Zn}$; the materials were melted at $600{ }^{\circ} \mathrm{C}$ for $30 \mathrm{~min}$ and then poured in a steel mold to produce the chill cast ingot. The solder ingots were mechanically machined into wire samples with a gauge length of $5 \times 10^{-2} \mathrm{~m}$ and $1.2 \times 10^{-2} \mathrm{~m}$ in diameter. The samples were annealed at $150^{\circ} \mathrm{C}$ for $120 \mathrm{~min}$, then left to cool slowly to room temperature with cooling rate of $10^{\circ} \mathrm{C} / \mathrm{s}$ to obtain samples containing fine microstructure, fully precipitated phases and free from any plastic strain accumulation during machining. Creep testing was done at three working temperatures (298, 343 and 393K) monitored by a thermocouple contacting with the specimen (within accuracy of $\pm 1{ }^{\circ} \mathrm{C}$ ) and under constant applied stresses using a computerized testing machine. To understand the melting process of three solder alloys; differential scanning Calorimetry (Shimadzu DSC-50) (DSC) was carried out at heating rate of $\left(10^{\circ} \mathrm{C} / \mathrm{min}\right.$. $)$ in $\mathrm{Ar}$ flow. The microstructure was investigated by $\mathrm{X}$ ray diffraction (XRD) using Philips $X^{\prime}$ Pert (MPD) Goniometer PW3050/00 with graphite monochromatic using $\mathrm{Cu}-\mathrm{K}_{\alpha}$ target and $\mathrm{Ni}$ filter operated at $(40 \mathrm{~K} . \mathrm{V}$.) and $(30 \mathrm{~mA})$ to give radiation of a wave length $(\lambda=0.15406 \mathrm{~nm})$ has been carried out to identify the phases of alloy 
samples with diffraction angles $((2 \theta))$ from $25^{\circ}$ to $90^{\circ}$. Morphological studies have been conducted using both optical microscopy (OM) and scanning electron microscopy (SEM) after using an etching solution of $2 \% \mathrm{HCl}, 3 \% \mathrm{HNO}_{3}$ and $95 \%$ (vol. \%) ethyl alcohol.

\section{Results and Discussion}

$X$-ray diffraction analysis

X-ray diffraction investigations of Sn- $0.7 \mathrm{Cu}, \mathrm{Sn}$ $0.7 \mathrm{Cu}-2.0 \mathrm{Zn}$ and $\mathrm{Sn}-0.7 \mathrm{Cu}-2.0 \mathrm{Sb}$ LFSAs were studied to identify the phases formed through the solder matrix. Figure (1a) shows the XRD results of three alloys, which show: (i) large peaks intensity of $\beta$-Sn-rich phase, (ii) small peaks of $\mathrm{Cu}_{6} \mathrm{Sn}_{5}$ phases through the entire solders.

The microstructure of $\mathrm{Zn}$ - and Sb-containing solders shows additional IMCs of $\mathrm{Cu}_{5} \mathrm{Zn}_{8}$ and $\mathrm{SnSb}$, respectively, dispersed in $\beta$-Sn rich matrix Fig. (1 b and c). From the XRD analysis of Zncontaining solder, the intensity of $\beta$-Sn peak at $43.565^{\circ}$ was increased while the peak of the $\mathrm{Cu}_{6} \mathrm{Sn}_{5}$ at $42.725^{\circ}$ was decreased compared to the plain solder due to the formation of $\mathrm{Cu}_{5} \mathrm{Zn}_{8}$ IMCs in agreement with the previous work $[18,19]$. Figure $(1 \mathrm{c})$ shows the formation of $\mathrm{SnSb}$ IMC through the $\beta$-Sn matrix in addition to the small peak of $\mathrm{Cu}_{6} \mathrm{Sn}_{5}$ IMCs. Moreover, the intensities of $\beta$-Sn and $\mathrm{Cu}_{6} \mathrm{Sn}_{5}$ phases were found to decrease with the addition of either $\mathrm{Zn}$ or Sb elements. X- ray lattice parameters (a \& c) for the three alloys have been calculated and listed in Table (2).

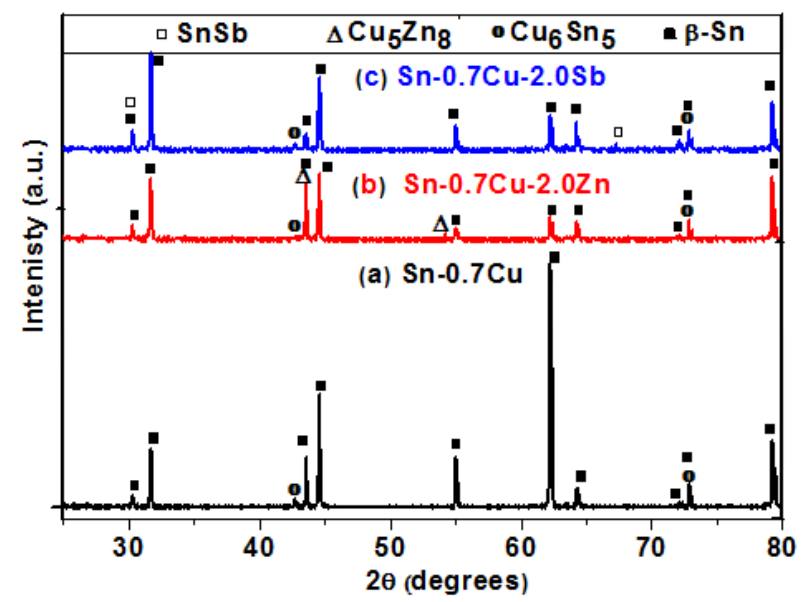

Fig. (1): X-Ray Diffraction of (a) $\mathrm{Sn-0.7Cu}$, (b) Sn-0.7Cu2.0Zn and (c) Sn-0.7Cu-2.0Sb lead free solder alloys

The results show that all parameters are sensitive to $\mathrm{Zn}$ or $\mathrm{Sb}$ additions. The apparent crystallite size $(L)$ for the main reflections (101) \& (112) planes after resolution of $K_{\alpha 1} \& K_{\alpha 2}$ intensities was calculated from the half maximum full width (HMFW) as shown in Fig. 2. For (112) reflection (as an example) and by using Sherrer equation (1) $[20,21]$, the crystallite sizes are tabulated in Tables ( 3 a and $\mathbf{b})$.

$$
L=K \lambda / B \cos \theta
$$

Where, $\mathrm{K}$ is Sherrer parameter equal to (0.9) for (HMFW)

Table (2): X-ray parameters

\begin{tabular}{|c|c|c|c|}
\hline Parameter & $\mathrm{Sn}-0.7 \mathrm{Cu}$ & $\mathrm{Sn}-0.7 \mathrm{Cu}-2 \mathrm{Zn}$ & $\mathrm{Sn}-0.7 \mathrm{Cu}-2 \mathrm{Sb}$ \\
\hline a & $5.8373 \pm 0.0011$ & $5.8158 \pm 0.0014$ & $5.8389 \pm 0.0012$ \\
\hline c & $3.3151 \pm 0.0081$ & $3.1867 \pm 0.0094$ & $3.1836 \pm 0.0008$ \\
\hline $\mathrm{c} / \mathrm{a}$ & 0.567918 & 0.54794 & 0.545232 \\
\hline \multicolumn{4}{|c|}{ Table (3 a): The crystallite size of $(112)$ reflection } \\
\hline Sample & \multicolumn{3}{|c|}{$\begin{array}{l}\text { Crystallite size }[\mathrm{L}(\mathrm{nm})] \text { of }(112) \text { reflection of } \mathrm{Sn}-0.7 \mathrm{Cu}, \mathrm{Sn}-0.7 \mathrm{Cu}- \\
2.0 \mathrm{Zn} \text { and } \mathrm{Sn}-0.7 \mathrm{Cu}-2.0 \mathrm{Sb} \text { solders }\end{array}$} \\
\hline $\mathrm{Sn}-0.7 \mathrm{Cu}$ & \multicolumn{3}{|c|}{145.0} \\
\hline $\mathrm{Sn}-0.7 \mathrm{Cu}-2 \mathrm{Zn}$ & \multicolumn{3}{|l|}{101.7} \\
\hline $\mathrm{Sn}-0.7 \mathrm{Cu}-2 \mathrm{Sb}$ & \multicolumn{3}{|c|}{134.0} \\
\hline \multicolumn{4}{|c|}{ Table (3 b): The crystallite size of (101) reflection } \\
\hline Sample & \multicolumn{3}{|c|}{$\begin{array}{l}\text { Crystallite size }[\mathrm{L}(\mathrm{nm})] \text { of }(101) \text { reflection of } \mathrm{Sn}-0.7 \mathrm{Cu}, \mathrm{Sn}-0.7 \mathrm{Cu}- \\
2.0 \mathrm{Zn} \text { and } \mathrm{Sn}-0.7 \mathrm{Cu}-2.0 \mathrm{Sb} \text { alloys }\end{array}$} \\
\hline $\mathrm{Sn}-0.7 \mathrm{Cu}$ & \multicolumn{2}{|c|}{102.5} & \\
\hline $\mathrm{Sn}-0.7 \mathrm{Cu}-2 \mathrm{Zn}$ & \multicolumn{2}{|c|}{84.6 .0} & \\
\hline $\mathrm{Sn}-0.7 \mathrm{Cu}-2 \mathrm{Sb}$ & \multicolumn{2}{|c|}{101.4} & \\
\hline
\end{tabular}


The results show that $L$ was decreased with the additions of either $\mathrm{Zn}$ or Sb elements. The $\mathrm{Zn}$ containing solder has the smallest crystallite size (84.6 and $101.7 \mathrm{~nm}$ ) compared to 102.5 and $145 \mathrm{~nm}$ of the plain solder alloy for both (101) and (112) planes, respectively. Alloying with $\mathrm{Sb}$ element shows a less decrease in crystallite sizes. These results explained the higher creep resistance of the $\mathrm{Zn}$-containing compared to that of Sb-containing solder.

\section{Thermal analysis}

A high-quality solder alloys should have a lower melting temperature and a narrow pasty range for electronic applications [22]. Thus, the melting temperature as a physical property is very important. Figure (3 a-c) shows the DSC curves of $\mathrm{Sn}-0.7 \mathrm{Cu}$, Sn-0.7Cu-2.0Zn and $\mathrm{Sn}-0.7 \mathrm{Cu}-2.0 \mathrm{Sb}$ solders.

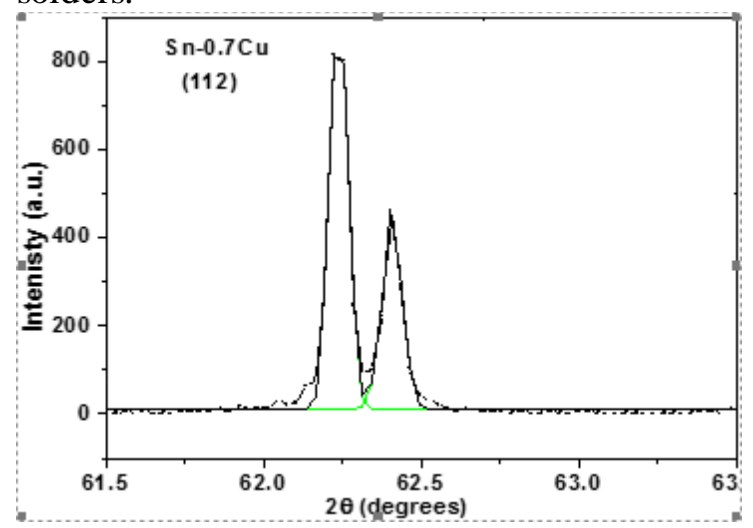

Fig. (2): Resolution of (112) plane

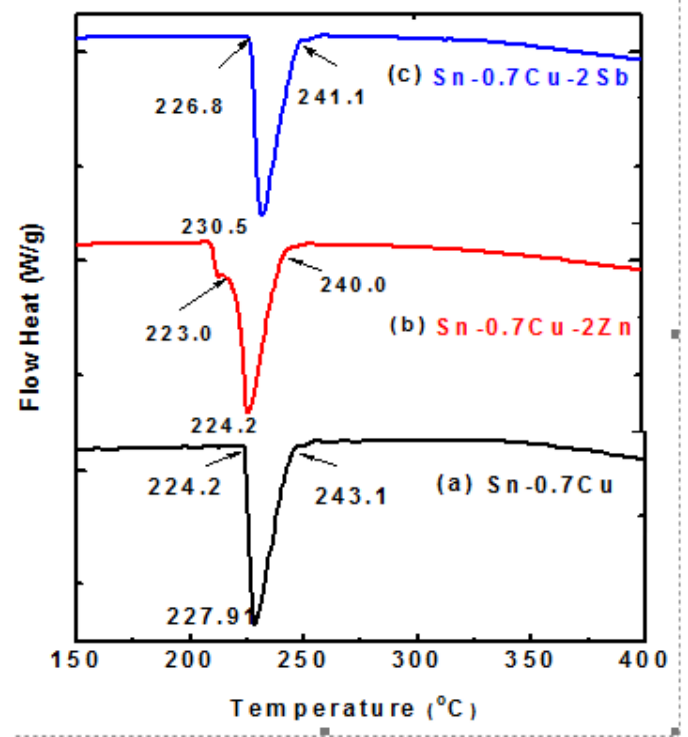

Fig. (3): DSC curves of (a) $\mathrm{Sn-0.7Cu}$ (b) Sn-0.7Cu-2.0Zn

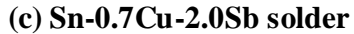

In Fig. (3 a), the eutectic temperature of $\mathrm{Sn}-0.7 \mathrm{Cu}$ solder at the endothermic peak is $227.9^{\circ} \mathrm{C}$, which is in quite agreement with the previous work [10]. With the addition of $2 \mathrm{Zn}$ to $\mathrm{Sn}-0.7 \mathrm{Cu}$ alloy, the endothermic peak temperature was significantly reduced to $224.2{ }^{\circ} \mathrm{C}$ owing to the dissolution of small amount of $\mathrm{Cu}_{6} \mathrm{Sn}_{5}$ in the $\beta$-tin matrix, as seen in Fig. (3 b). The eutectic temperature of $\mathrm{Sn}-0.7 \mathrm{Cu}$ solder alloy containing $2 \mathrm{wt} \% \mathrm{Sb}$ was increased from $227.9^{\circ} \mathrm{C}$ to $230.5{ }^{\circ} \mathrm{C}$ as shown in Fig. $(3 \mathrm{c})$. The increase in endothermic peak was attributed to the formation of $\mathrm{SnSb}$ cuboids (confirmed by EDS analysis) as IMC particles, which float at the surface of solder during solidification before the formation of $\mathrm{Cu}_{6} \mathrm{Sn}_{5}$ in $\beta$-tin matrix [23]. The pasty range, which is the difference between solidus $\left(T_{\text {onset }}\right)$ and liquidus temperatures $\left(T_{\text {end }}\right)$, was found to decrease with $\mathrm{Zn}$ or $\mathrm{Sb}$ addition from $18.9^{\circ} \mathrm{C}$ to $17{ }^{\circ} \mathrm{C}$ and $14.2{ }^{\circ} \mathrm{C}$, respectively. The heat of fusion $(\Delta H)$ equation for any material [24] is given by:-

$$
\Delta H=\frac{K A}{m}
$$

Where, $K$ is constant depends on a crucible shape of the DSC system, $m$ is the sample mass and $A$ is the area under the endothermic peak. Table (4) listed the values of $T_{\text {onset }}, T_{\text {end }}$, pastry ranging ( $T_{\text {end }}$ $-T_{\text {onset }}$ ), and $\Delta H$ of three solders. The results showed that the addition of $\mathrm{Zn}$ to the eutectic Sn$0.7 \mathrm{Cu}$ solder reduced the eutectic temperature from $227.91{ }^{\circ} \mathrm{C}$ to $224.20{ }^{\circ} \mathrm{C}$ and decreased both of the pastry ranging from $18.9-17.0$ and the heat of fusion from 45.48 to $35.36 \mathrm{~J} / \mathrm{g}$, which indicated that the $\mathrm{Zn}$-containing solder is the best solder for saving energy.

The effect of Zn and Sb additions on microstructure Microstructure plays a vital role to create high quality solder alloys and to explain their mechanical behavior. Figure (4 a) shows an OM microstructure of $\mathrm{Sn}-0.7 \mathrm{Cu}$ solder with a gray phase of $\mathrm{Cu}_{6} \mathrm{Sn}_{5}$ particles and dark phase of $\beta-\mathrm{Sn}$ matrix besides the eutectic phase. The addition of 2 wt. \% $\mathrm{Zn}$ into $\mathrm{Sn}-0.7 \mathrm{Cu}$ solder refined the $\mathrm{Cu}_{6} \mathrm{Sn}_{5}$ particles and created a fine IMCs of $\mathrm{Cu}-\mathrm{Zn}$ phase through $\beta$-Sn matrix as shown in Fig. $(4 \mathrm{~b})$, which is confirmed by EDS investigation shown in Fig. (5 e). Conversely, the addition of 2 wt.\% Sb created new IMC particles of $\mathrm{SnSb}$ (gray phase), besides the formation of $\mathrm{Cu}_{6} \mathrm{Sn}_{5}$ IMC (bright) through the $\beta$-Sn matrix (Fig. 4 c). 
Table (4): The DSC results of $\mathrm{Sn}-0.7 \mathrm{Cu}, \mathrm{Sn}-0.7 \mathrm{Cu}-2 \mathrm{Zn}$ and $\mathrm{Sn}-0.7 \mathrm{Cu}-2 \mathrm{Sb}$ solders

\begin{tabular}{llllll}
\hline \multicolumn{1}{c}{ Alloy } & $\mathrm{T}_{\text {onset }}\left({ }^{\circ} \mathrm{C}\right)$ & $\mathrm{T}_{\text {end }}\left({ }^{\circ} \mathrm{C}\right)$ & $\begin{array}{c}\text { Melting } \\
\text { temperature }\left({ }^{\circ} \mathrm{C}\right)\end{array}$ & $\begin{array}{c}\text { Pastry range } \\
\left({ }^{\circ} \mathrm{C}\right)\end{array}$ & $\Delta \mathrm{H}(\mathrm{J} / \mathrm{g})$ \\
\hline $\mathrm{Sn}-0.7 \mathrm{Cu}$ & 224.20 & 243.10 & 227.91 & 18.90 & 45.48 \\
$\mathrm{Sn}-0.7 \mathrm{Cu}-2 \mathrm{Zn}$ & 223.00 & 240.00 & 224.20 & 17.00 & 35.36 \\
$\mathrm{Sn}-0.7 \mathrm{Cu}-2 \mathrm{Sb}$ & 226.80 & 241.10 & 230.50 & 14.20 & 39.43 \\
\hline
\end{tabular}
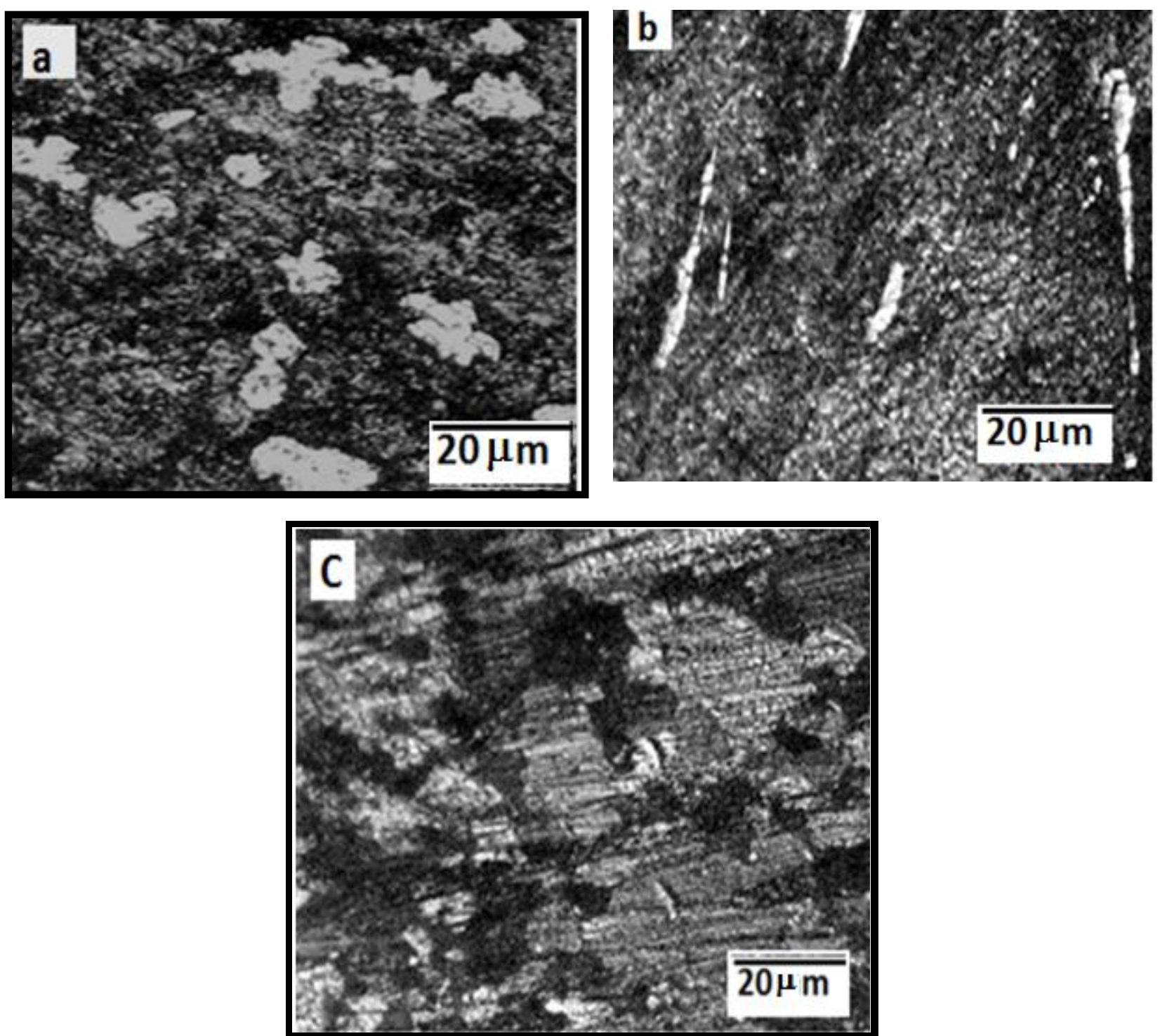

Fig. (4): OM micrographs of (a) Sn-0.7 Cu, (b) Sn-0.7 Cu-2.0Zn and (c) Sn-0.7 Cu-2.0 Sb solder alloys 

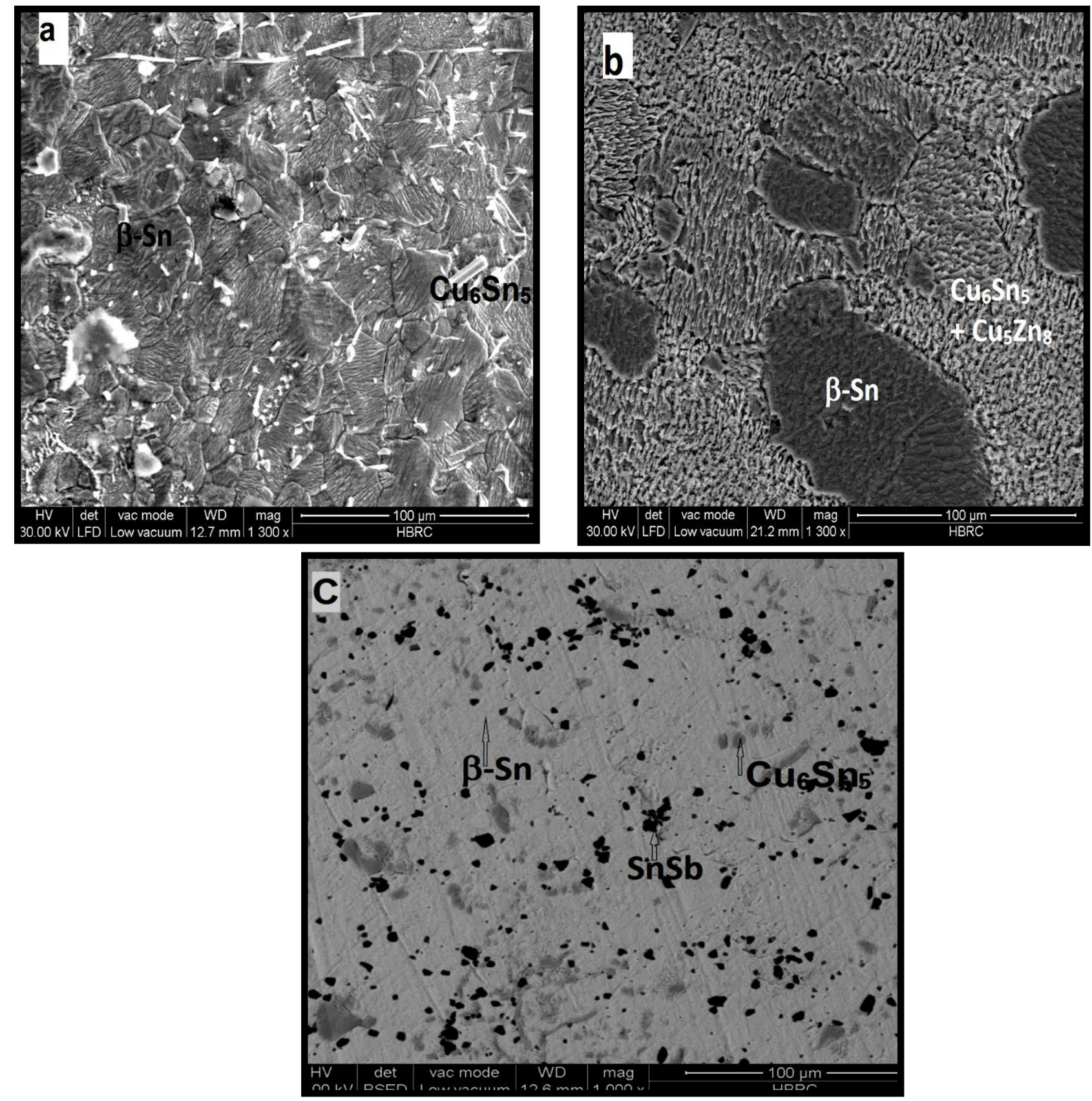

Fig. (5): Shows SEM micrographs of (a) Sn-0.7 Cu (b) Sn-0.7 Cu-2.0 Zn and (c) Sn-0.7 Cu-2.0 Sb solders 


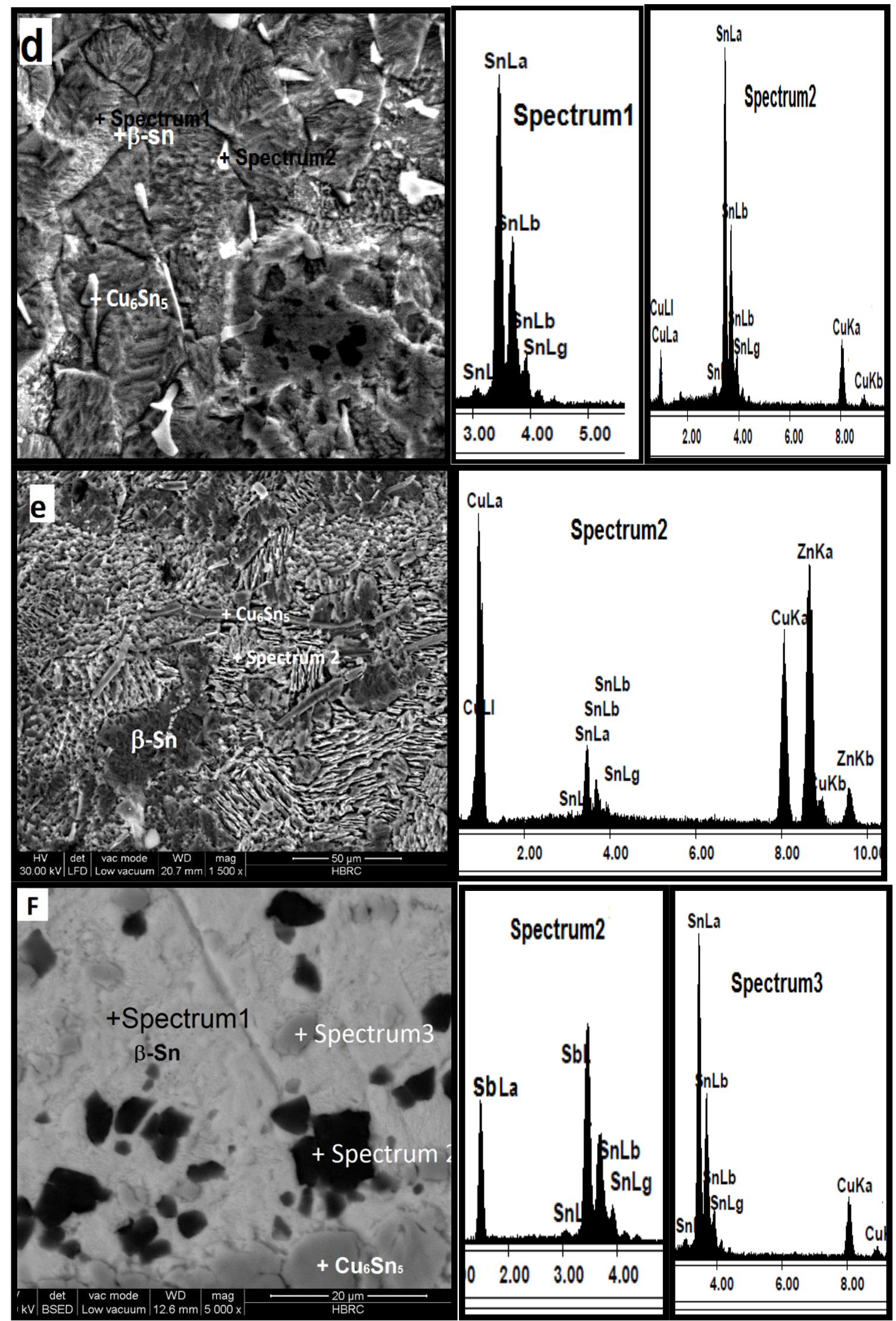

Fig. (5 d, e, f): Shows SEM, EDX micrographs of (d) Sn-0.7 Cu (e) Sn-0.7 Cu-2.0 Zn and (f) Sn-0.7 Cu-2.0 Sb solders 
Figure (5 a, b, c) shows SEM micrographs as a comparison of microstructures between $\mathrm{Sn}-0.7 \mathrm{Cu}$, $\mathrm{Sn}-0.7 \mathrm{Cu}-2.0 \mathrm{Zn}$ and $\mathrm{Sn}-0.7 \mathrm{Cu}-2.0 \mathrm{Sb}$ alloys. Figure (5 d) shows the high magnification microstructure of $\mathrm{Sn}-0.7 \mathrm{Cu}$ solder, which consists of two phases: (i) needle-like $\mathrm{Cu}_{6} \mathrm{Sn}_{5}$ particles of $0.9 \mu \mathrm{m}$, (ii) the $\beta$-tin grains $(15 \mu \mathrm{m})$ as identified by EDS analysis and x-ray diffraction (Fig. 1 a). The EDS results in Fig. (5 e) shows that the addition of $2.0 \% \mathrm{Zn}$ to $\mathrm{Sn}-0.7 \mathrm{Cu}$ alloy leads to the formation of new fiber-like $\mathrm{Cu}_{5} \mathrm{Zn}_{8}$ IMCs $(0.5 \mu \mathrm{m})$ and reduced the needle-like $\mathrm{Cu}_{6} \mathrm{Sn}_{5}(0.3 \mu \mathrm{m})$ phase in $\beta$-tin matrix. The results are in agreement with previous works $[\mathbf{1 8}, \mathbf{1 9}, \mathbf{2 5}]$. The presence of the small particle size of $\mathrm{Cu}_{6} \mathrm{Sn}_{5}$ and $\mathrm{Cu}_{5} \mathrm{Zn}_{8}$ in $\beta$-tin matrix are confirmed by the EDS (Fig. 5 e) and Xray diffraction patterns (Fig. 1 b). The IMCs $\mathrm{Cu}_{6} \mathrm{Sn}_{5}$ and $\mathrm{Cu}_{5} \mathrm{Zn}_{8}$ could act as obstacles, which resist the motion of dislocations. The addition of $2.0 \%$ of $\mathrm{Sb}$ to $\mathrm{Sn}-0.7 \mathrm{Cu}$ creates a new phase of $\mathrm{SnSb}$ cuboids $(2.0 \mu \mathrm{m})$ of IMCs besides the $\mathrm{Cu}_{6} \mathrm{Sn}_{5}$ $(1.2 \mu \mathrm{m})$ particles extended in the $\beta$-tin matrix as confirmed by EDS (Fig. 5 f) and X-ray diffraction (Fig. 1 c). The SEM investigations also showed a less amount of $\mathrm{Cu}_{6} \mathrm{Sn}_{5}$. IMCs in $\mathrm{Sn}-0.7 \mathrm{Cu}-2.0 \mathrm{Sb}$ than that of $\mathrm{Sn}-0.7 \mathrm{Cu}$ and $\mathrm{Sn}-0.7 \mathrm{Cu}-2.0 \mathrm{Zn}$ solders due to the formation of $\mathrm{SnSb}$ phase at the beginning of solidification process before the $\mathrm{Cu}_{6} \mathrm{Sn}_{5}$ particles formation. Figure (5 f) shows gray particles of $\mathrm{Cu}_{6} \mathrm{Sn}_{5}$ and dark particles of $\mathrm{SnSb}$ through $\beta$-tin phase. The particle sizes of all phases have been calculated and listed in Table (5).

The results show that the addition of $\mathrm{Zn}$ and $\mathrm{Sb}$ increased the $\beta$-Sn grain size $(18-35 \mu \mathrm{m})$; whereas the addition of $\mathrm{Zn}$ created a new small size of $\mathrm{Cu}_{5} \mathrm{Zn}_{8}$ particles $(0.5 \mu \mathrm{m})$ and reduced the $\mathrm{Cu}_{6} \mathrm{Sn}_{5}$ particle size from $0.9 \mu \mathrm{m}$ to $0.3 \mu \mathrm{m}$. The Sb-addition created $\mathrm{SnSb}$ IMCs with an average size of $\sim 2.0 \mu \mathrm{m}$ and increased the $\mathrm{Cu}_{6} \mathrm{Sn}_{5}$ particles size to $\sim 0.9-1.2 \mu \mathrm{m}$. The ${ }^{()}$ growth in particles size of $\mathrm{Sn}-0.7 \mathrm{Cu}-\mathrm{Sb}$ leads to initiate small cracks during creep tests, which explains the decrease in its creep resistance and fracture time.

\section{Creep properties}

Creep curves for the three solder alloys were carried out at three working temperatures (298K, $343 \mathrm{~K}$ and $393 \mathrm{~K})$ and under different applied stresses (7.8-19.6 MPa). Figure (6 a-c) shows the creep behavior of $\mathrm{Sn}-0.7 \mathrm{Cu}, \mathrm{Sn}-0.7 \mathrm{Cu}-2.0 \mathrm{Zn}$ and $\mathrm{Sn}-0.7 \mathrm{Cu}-2.0 \mathrm{Sb}$ solder materials tested at 298, 343 and $393 \mathrm{~K}$ and under constant applied stress $(12.7,11.7$ and $9.8 \mathrm{MPa})$, respectively. On the other hands, Fig. (6 d) presents the effect of different applied stresses at $298 \mathrm{~K}$ on $\mathrm{Sn}-0.7 \mathrm{Cu}$ alloy.

Figure (7 a-c) shows the creep rate-time curves at different temperatures and loads for $\mathrm{Sn}-0.7$ $\mathrm{Cu}, \mathrm{Sn}-0.7 \mathrm{Cu}-2.0 \mathrm{Zn}$ and $\mathrm{Sn}-0.7 \mathrm{Cu}-2.0 \mathrm{Sb}$, respectively. Typical creep curves consist of three stages; primary (transient) creep, secondary (steady state) creep and tertiary creep (fracture stage). They indicated that the Sn-0.7 $\mathrm{Cu}-2.0 \mathrm{Zn}$ has the lowest creep rate followed by Sn-0.7 Cu, whereas the highest creep rate was for $\mathrm{Sn}-0.7 \mathrm{Cu}-2.0 \mathrm{Sb}$ alloy. The effect of $\mathrm{Zn}$ addition to the microstructure of $\mathrm{Sn}-0.7 \mathrm{Cu}$ solder alloy creates a new IMCs of $\mathrm{Cu}_{5} \mathrm{Zn}_{8}$ with $0.5 \mu \mathrm{m}$ size besides reducing the needle size of $\mathrm{Cu}_{6} \mathrm{Sn}_{5}(0.3 \mu \mathrm{m})$ inside the $\beta$-Sn matrix. The presence of fine dispersive $\mathrm{Cu}_{5} \mathrm{Zn}_{8} \& \mathrm{Cu}_{6} \mathrm{Sn}_{5}$ particles could act as a pinning effect to the dislocation motion, which enhanced the creep resistance of Zn-containing solders. The microstructure of $\mathrm{Sb}$-containing solders consists of cuboids of SnSb $(2.0 \mu \mathrm{m})$ and large size of $\mathrm{Cu}_{6} \mathrm{Sn}_{5}(1.2 \mu \mathrm{m})$ in the $\beta$-Sn matrix. During the creep process, the coarse ( $\mathrm{SnSb}$ and $\mathrm{Cu}_{6} \mathrm{Sn}_{5}$ ) IMCs creates a crack propagation path [26], which leads to a decrease in the creep resistance of $\mathrm{Sn}-0.7 \mathrm{Cu}-2.0 \mathrm{Sb}$ solder.

\section{Transient creep}

Using the transient creep equation [27]

$$
\begin{aligned}
& \varepsilon_{t r}=\beta t^{n} \\
& \ln \varepsilon_{t r}=\ln \beta+n \ln t
\end{aligned}
$$

Where, $\mathrm{n}$ and $\beta$ are the transient creep parameters that depend on both the working temperature and applied stress. The parameter $n$ usually has a value in the range of $0<n<1$. Figure $(\mathbf{8}$ a- $\mathbf{c})$ shows the relations between $\ln \varepsilon_{t r}$ against $\ln t$ for wire specimens of the $\mathrm{Sn}-0.7 \mathrm{Cu}, \mathrm{Sn}-0.7 \mathrm{Cu}-2 \mathrm{Z} \mathrm{n}$ and Sn-0.7 Cu-2Sb tested at (298K, $12.7 \mathrm{MPa}),(343$ $\mathrm{K}, 11.7 \mathrm{MPa})$ and $(393 \mathrm{~K}, 9.8 \mathrm{MPa})$, respectively. 
Table (5): Phases particle size of $\mathrm{Sn0.7Cu}, \mathrm{Sn} 0.7 \mathrm{Cu}-2 \mathrm{zn}$ and $\mathrm{Sn0.7Cu-2Sb}$ alloys

\begin{tabular}{lllll}
\hline \multirow{2}{*}{ Alloy } & & \multicolumn{2}{l}{ Particle Size $(\mu \mathrm{m})$} \\
$\mathrm{Cu}_{5}$ & $\beta$-tin & $\mathrm{Cu}_{6} \mathrm{Sn}_{5}$ & $\mathrm{SnSb}$ \\
\hline $\mathrm{Sn}-0.7 \mathrm{Cu}$ & 18 & 0.9 & - & - \\
$\mathrm{Sn}-0.7 \mathrm{Cu}-2.0 \mathrm{Zn}$ & 25 & 0.3 & 0.5 & - \\
$\mathrm{Sn}-0.7 \mathrm{Cu}-2.0 \mathrm{Sb}$ & 35 & 1.2 & - & 2.0 \\
\hline
\end{tabular}
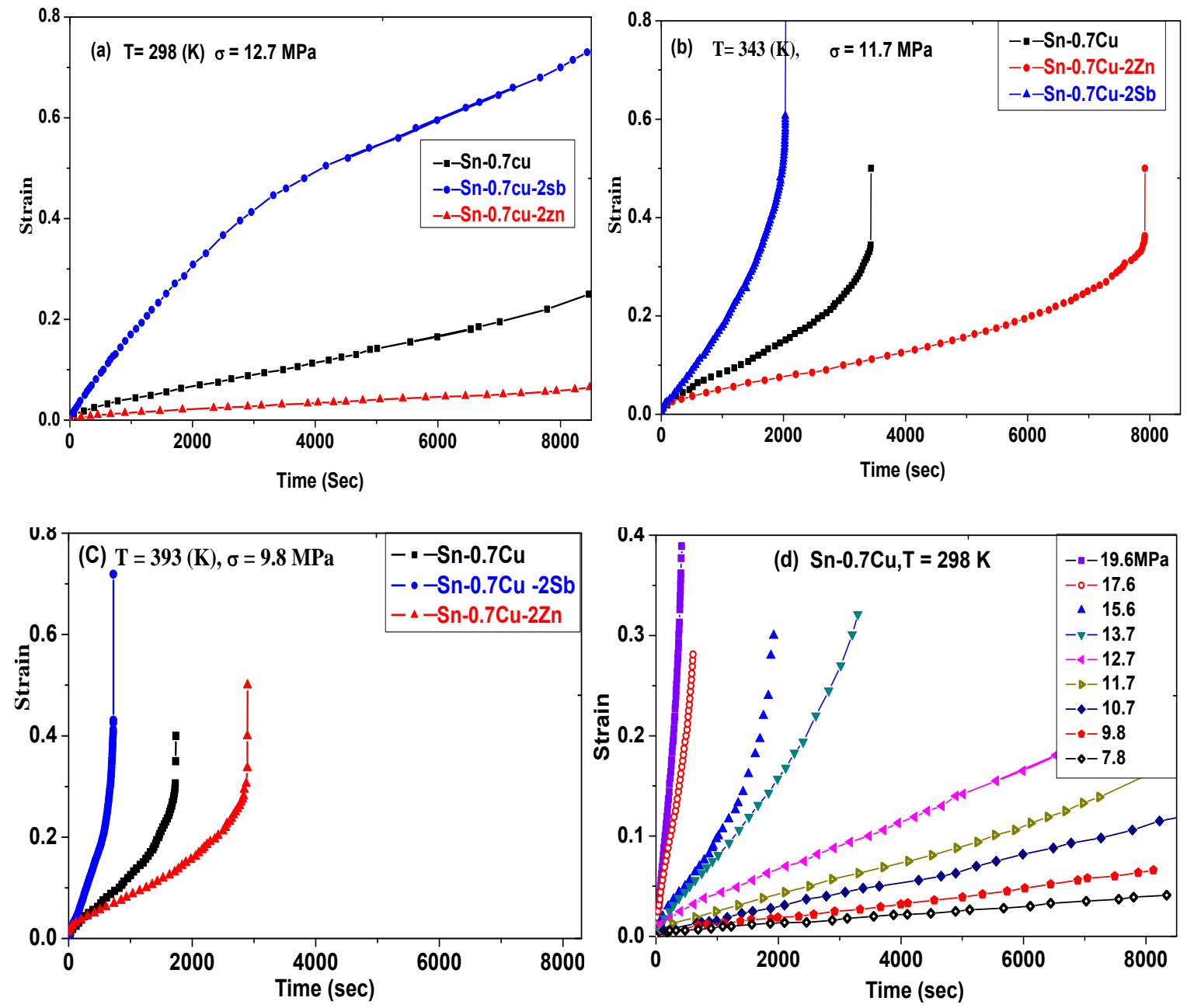

Fig. (6): Shows the creep behavior at (a) 298K, 12.7 MPa, (b) 343K, 11.7 MPa, (c) 393K, 9.8 MPa for Sn-0.7 Cu, Sn-0.7 Cu2.0 $\mathrm{Zn}$ and $\mathrm{Sn-0.7} \mathrm{Cu}-2.0 \mathrm{Sb}$ and (d) $298 \mathrm{~K}$ for $\mathrm{Sn-0.7} \mathrm{Cu}$ solder under different applied stresses 

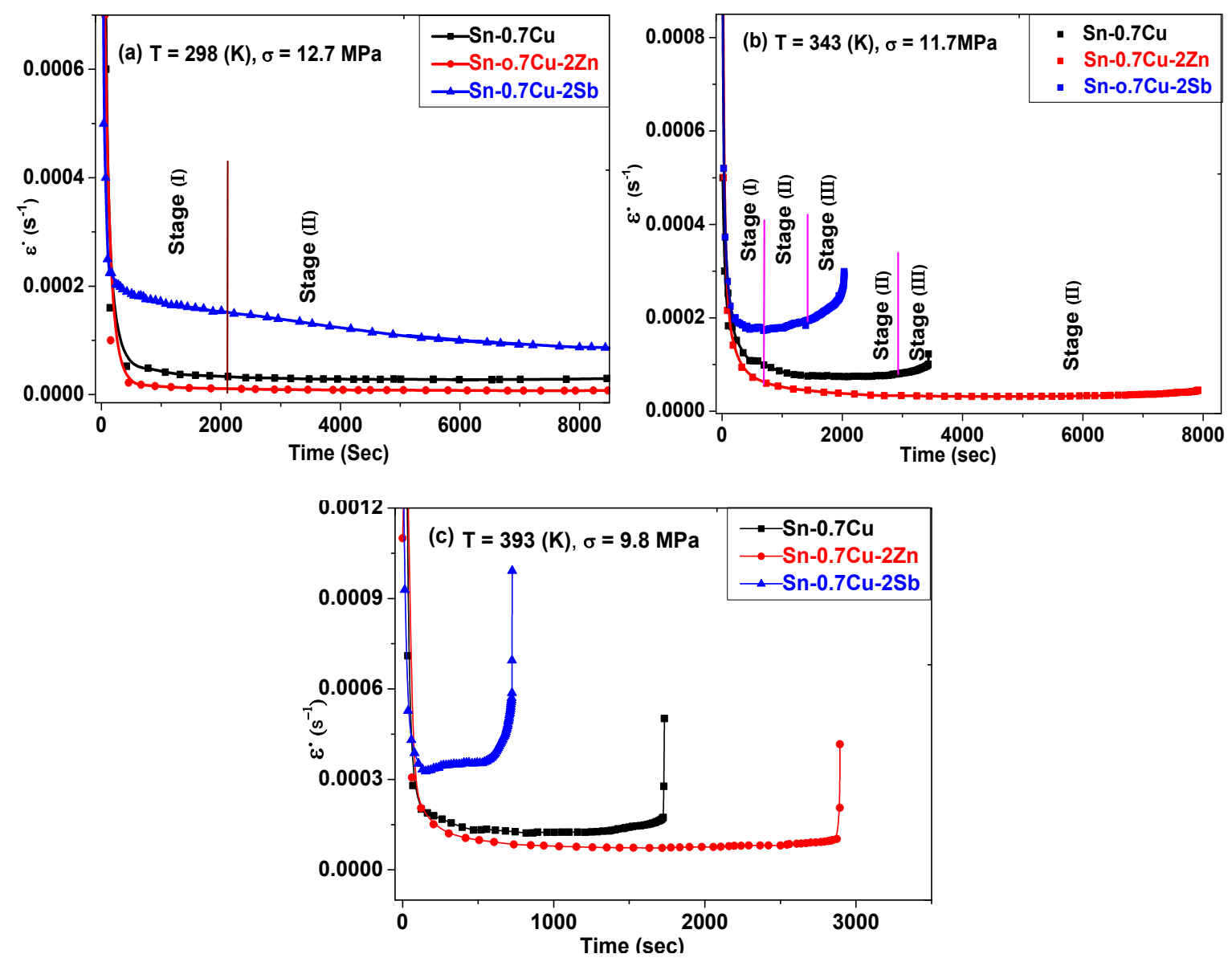

Fig. (7): shows strain rate - time relationships at a) $298 \mathrm{~K}, 12.7 \mathrm{MPa}$, (b) 343K, $11.7 \mathrm{MPa}$ and (c) $393 \mathrm{~K}, 9.8 \mathrm{MPa}$ for Sn-0.7

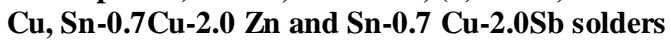

The transient creep mechanism in stage I depends on $\beta$ and $n$ parameters obtained from the relation between $\ln \varepsilon_{t r}$ and $\ln \mathrm{t}$ (Fig. $7 \mathbf{a}$ - c). The calculated parameters are listed in Table (6).

Figure $(\mathbf{9} \mathbf{a}, \mathbf{b})$ shows that the transient parameters $n$ and $\beta$ depend on both of creep test temperature and solder addition, which attributed to the change in the microstructure. It is clear that the increase in the parameter $n$ and the decrease in $\beta$ at the high temperature $(393 \mathrm{~K})$ may be attributed to the generation of new dislocations through the dislocation network.

\section{Steady state parameters}

of steady state creep rate $\varepsilon_{s}$ on the applied stress $(\sigma)$ and temperature $T$ can be expressed using Norton power law [28]:

$$
\varepsilon_{s}=A \sigma^{m} \exp (-Q / R T)
$$

$\ln \varepsilon^{\cdot}{ }_{s}=\ln A+m \ln \sigma-Q / R T$

Where, A is constant depends on the material structural properties, $\mathrm{m}$ is the stress exponent. At a given temperature, the creep stress exponent $(\mathrm{m})$ can be calculated from the relation between $\ln \sigma$ against $\ln \varepsilon_{s}$, and the activation energy $(Q)$ can be obtained from the relation between $\ln \varepsilon_{s}$ against $\ln (1000 / T)$. Figure (10) shows the dependence of stress exponent $(\mathrm{m})$ on the creep test temperatures and alloying element additions. 

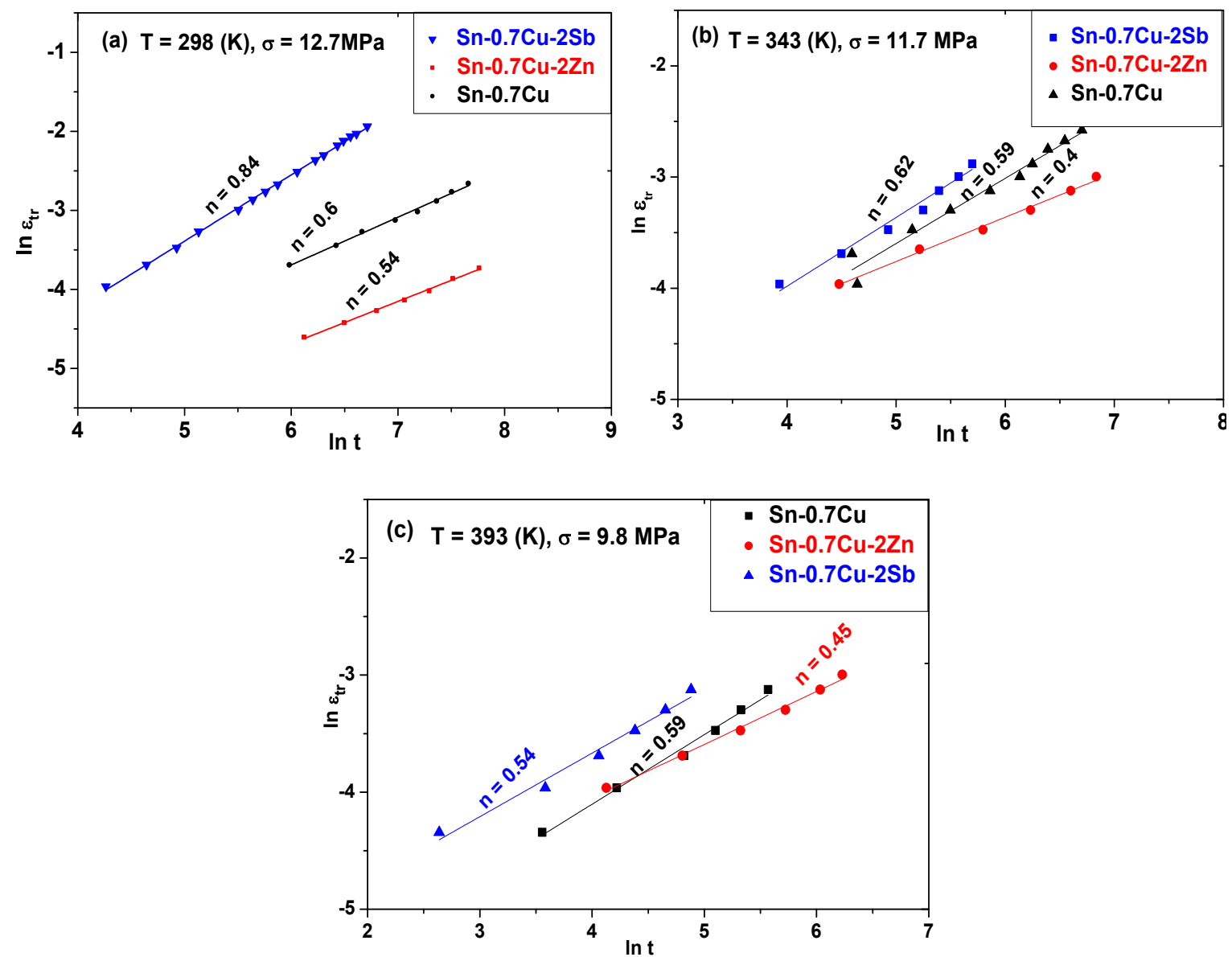

Fig. (8): Shows the relations between $\ln \varepsilon_{t r}$ against $\ln t$ for $\mathrm{Sn}-0.7 \mathrm{Cu}, \mathrm{Sn}-0.7 \mathrm{Cu}-2 \mathrm{Zn}$ and $\mathrm{Sn}-0.7 \mathrm{Cu}-2 \mathrm{Sb}$ alloys tested at (a) $298 \mathrm{~K}$, (b) $343 \mathrm{~K}$ and (c) $393 \mathrm{~K}$

Table (6): Transient parameters $(\mathrm{n} \& \beta)$

\begin{tabular}{lcccccc}
\hline Solder alloy & \multicolumn{2}{c}{$298(\mathrm{~K})$} & \multicolumn{2}{c}{$343(\mathrm{~K})$} & \multicolumn{2}{c}{$393(\mathrm{~K})$} \\
& $\mathrm{n}$ & $\beta$ & $\mathrm{n}$ & $\beta$ & \multicolumn{2}{c}{$\mathrm{n}$} \\
\hline $\mathrm{Sn}-0.7 \mathrm{Cu}$ & 0.60 & -7.30 & 0.59 & -6.50 & 0.59 & -6.50 \\
$\mathrm{Sn}-0.7 \mathrm{Cu}-2.0 \mathrm{Zn}$ & 0.54 & -7.90 & 0.40 & -5.80 & 0.45 & -5.90 \\
$\mathrm{Sn}-0.7 \mathrm{Cu}-2.0 \mathrm{Sb}$ & 0.84 & -7.58 & 0.62 & -6.50 & 0.54 & -5.80 \\
\hline
\end{tabular}
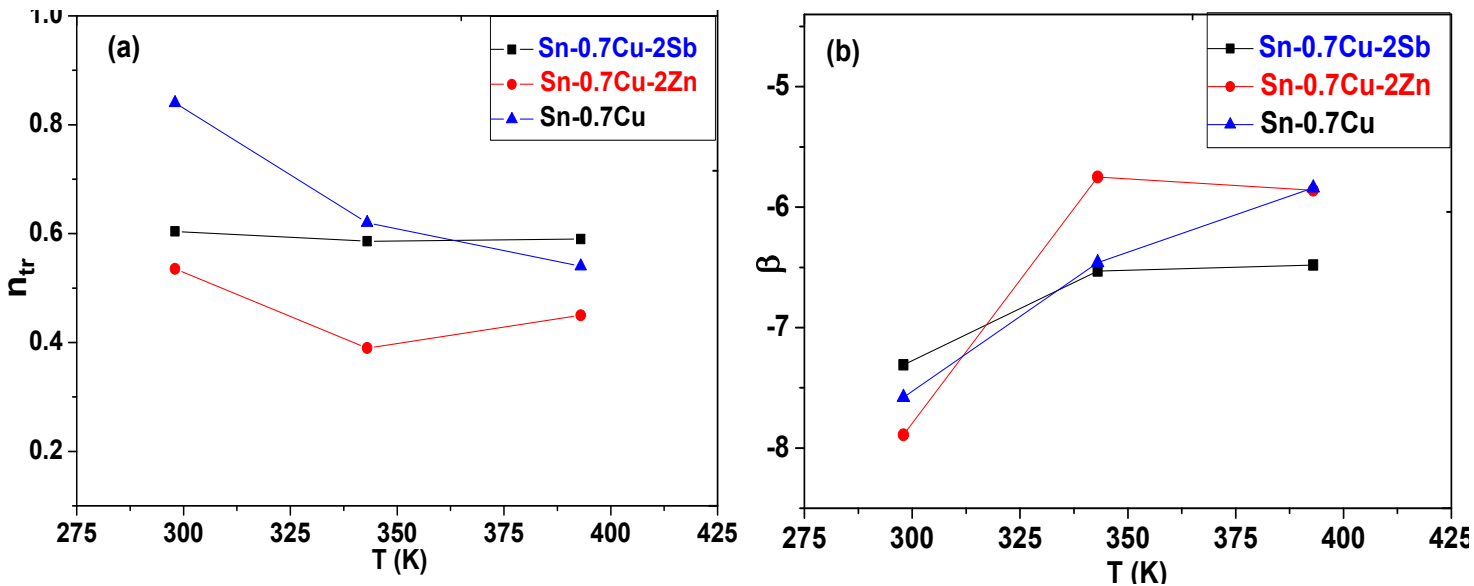

Fig. (9): Dependence of (a) the exponent $\left(n_{\mathrm{tr}}\right)$ and $(\mathrm{b})$ the exponent $(\beta)$ on the working temperature for Sn-0.7 Cu, Sn-0.7 $\mathrm{Cu}-2 \mathrm{Zn}$ and $\mathrm{Sn-0.7} \mathrm{Cu}-2 \mathrm{Sb}$ alloys 
Table (7) indicates that by increasing the working temperature; the stress exponent $(\mathrm{m})$ decreases and, in the same time, becomes very sensitive with the solder additions. The estimated $m$ values of the $\mathrm{Sn}-0.7 \mathrm{Cu}$ solder at 298,343 and $393 \mathrm{~K}$ were 5.8 , 5.2 and 4.3 , which are in agreement with the obtained values by El-Daly et.al [14].

Table (7): Stress exponent values (m) and activation energy (Q) for $\mathrm{Sn}-0.7 \mathrm{Cu}, \mathrm{Sn}-0.7 \mathrm{Cu}-2.0$ $\mathrm{Zn}$ and $\mathrm{Sn}-0.7 \mathrm{Cu}-2.0 \mathrm{Sb}$ alloys

The stress exponent $m$ plays an important role to identify the mechanisms controlling the deformation process; $(\mathrm{m} \approx 3$ represents a viscous glide and $\mathrm{m} \geq 4$ dislocation climb [29]). The experimental results show that the $\mathrm{Sn}-0.7 \mathrm{Cu}$, Sn$0.7 \mathrm{Cu}-2 \mathrm{Zn}$ and $\mathrm{Sn}-0.7 \mathrm{Cu}-2 \mathrm{Sb}$ solders have the stress exponents $m ;(5.8,5.2,4.3),(7.0,5.9,5.1)$ and $(5.3,5.0,4.5)$ correspond to the test temperatures $298 \mathrm{~K}, 343 \mathrm{~K}$ and $393 \mathrm{~K}$, respectively. The values of $m$ suggest that the creep deformation mechanism is the dislocation climb, which attributed to the precipitation - strengthening of the
$\mathrm{Cu}_{6} \mathrm{Sn}_{5}, \mathrm{Cu}_{5} \mathrm{Zn}_{8}$ and $\mathrm{SnSb}$ IMCs as shown in Table (7). Figure (11) shows the linear relationship of strain rate-temperature dependence. The calculated values of $m$ and $Q$ are listed in Table (7).

It is clearly shown that the $m$ value decreases at constant temperature with the addition of Sbelement to $\mathrm{Sn}-0.7 \mathrm{Cu}$ alloy, which was attributed to the change of microstructure due to the formation of $\mathrm{SnSb}$ particles and the coarsening of the $\mathrm{Cu}_{6} \mathrm{Sn}_{5}$ (IMCs) through $\beta$-Sn matrix. The $\mathrm{Zn}$ containing solder shows an increasing in the stress exponent $(m)$ values (4.3-7.0); due to the refining of $\mathrm{Cu}_{6} \mathrm{Sn}_{5}$ IMCs. Also, the $m$ values decrease by increasing the working temperature owing to the instability of microstructure. The $Q$ value of plain solder is $\sim 55 \mathrm{KJ} / \mathrm{mol}$, which increased to $\sim 60$ $\mathrm{KJ} / \mathrm{mol}$ with $\mathrm{Zn}$ addition, but decreased to $\sim 50$ $\mathrm{KJ} / \mathrm{mol}$ with the addition of Sb-element. On the basis of the stress exponent and the activation energy values; it is suggested that dislocation climb creep is the dominant deformation mechanism controlled by lattice diffusion [30].
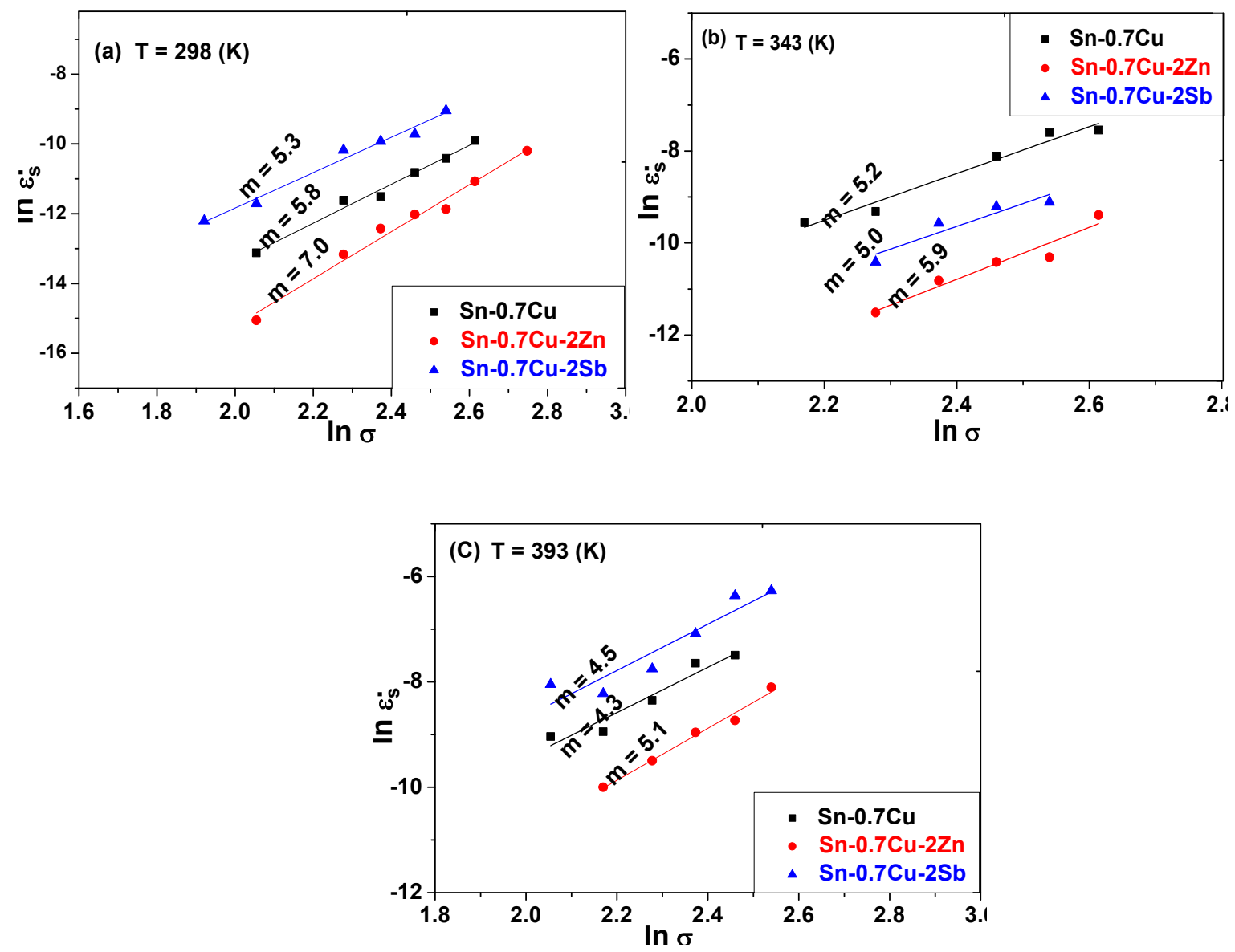

Fig. (10): The relation between $\mathrm{ln} \varepsilon_{\mathrm{s}}$ against $\mathrm{ln} \sigma$ for $\mathrm{Sn}-0.7 \mathrm{Cu}, \mathrm{Sn}-0.7 \mathrm{Cu}-2 \mathrm{Z} \mathrm{n}$ and $\mathrm{Sn}-0.7 \mathrm{Cu}-2 \mathrm{Sb}$ alloys at (a) $298 \mathrm{~K}$, (b) $343 \mathrm{~K}$ and (c) $393 \mathrm{~K}$ 
Table (7): Stress exponent values (m) and activation energy (Q) for Sn-0.7 Cu, Sn-0.7 Cu-2.0 Zn and Sn-0.7 Cu-2.0 Sb alloys

\begin{tabular}{lccl}
\hline Alloy & Q (kJ/mol) & Temperature $(\mathrm{K})$ & $\mathrm{m}$ \\
\hline Sn-0.7Cu & 55.0 & 298 & 5.8 \\
& & 343 & 5.2 \\
& & 393 & 4.3 \\
Sn-0.7Cu-2.0Zn & 60.0 & 298 & 7.0 \\
& & 343 & 5.9 \\
Sn-0.7Cu-2.0Sb & 50.0 & 393 & 5.1 \\
& & 298 & 5.3 \\
& & 343 & 5.0 \\
\hline
\end{tabular}

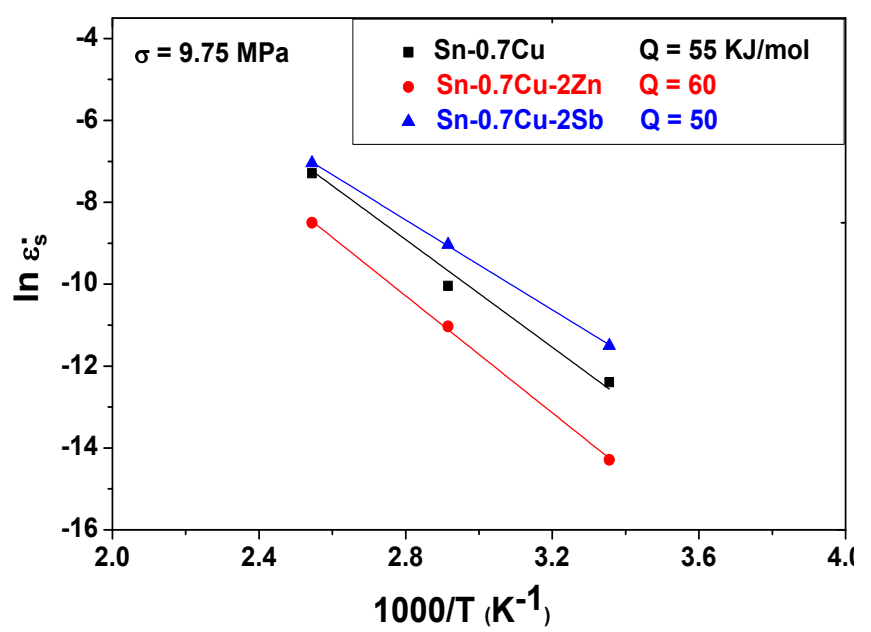

Fig. (11): Linear relationships of the strain rate-temperature of $\mathrm{Sn}-0.7 \mathrm{Cu}, \mathrm{Sn}-0.7 \mathrm{Cu}-2 \mathrm{Zn}$ and $\mathrm{Sn}-0.7 \mathrm{Cu}-2 \mathrm{~S}$ b alloys crept at 9.8 MPa

\section{Conclusions}

Three lead free solders Sn-0.7 wt.\% $\mathrm{Cu}, \mathrm{Sn}-0.7$ wt. $\% \mathrm{Cu}-2.0$ wt. $\% \mathrm{Zn}$ and $\mathrm{Sn}-0.7$ wt.\% $\mathrm{Cu}-2.0$ wt. $\% \mathrm{Sb}$ were conducted to analyze the effect of $\mathrm{Zn}$ and $\mathrm{Sb}$ additions on the microstructure, melting point and creep behavior of $\mathrm{Sn}-0.7$ wt.\% $\mathrm{Cu}$ solders. The conclusions are summarized as follows:

1. The Zn-containing solder showed a superior creep resistance due to the strengthening effect of fine dispersion $\mathrm{Cu}_{6} \mathrm{Sn}_{5}$ particles as well as the formation of the fine particles of $\mathrm{Cu}_{5} \mathrm{Zn}_{8}$ (IMCs) in $\beta$-Sn matrix.

2. The addition of Sb-element to $\mathrm{Sn}-0.7 \mathrm{Cu}$ alloy increases the strain rate of the creep behavior, which attributed to the crack path creation as a result of the $\mathrm{SnSb}$ (IMCs) formation, the coarsening of $\mathrm{Cu}_{6} \mathrm{Sn}_{5}$ particles and the growth of $\beta$-Sn grain size.
3. Using the DSC investigations, the addition of $\mathrm{Zn}$ to $\mathrm{Sn}-0.7 \mathrm{Cu}$ alloy decreased the melting point from 227.9 to $224.2^{\circ} \mathrm{C}$ although the addition of $\mathrm{Sb}$ element increased the melting point from $227.9^{\circ} \mathrm{C}$ to $230.9^{\circ} \mathrm{C}$.

4. Unlike Sb-element addition, the transient exponents $n$ of the plain alloy was decreased by increasing the testing temperature and the addition of $\mathrm{Zn}$-element

5. The stress exponents $(\mathrm{m})$ for lead-free solders are decreased by increasing the testing temperature due to the dissolution of the $\mathrm{Cu}_{6} \mathrm{Sn}_{5}$ phase at a high temperature.

6. On the basis of the average stress exponents 5.1, 6.0 and 4.9 and activation energies of 55.0 $\mathrm{KJ} / \mathrm{mol}, 60.0 \mathrm{KJ} / \mathrm{mol}$ and $50.0 \mathrm{KJ} / \mathrm{mol}$ for Sn$0.7 \mathrm{Cu}, \mathrm{Sn}-0.7 \mathrm{Cu}-2.0 \mathrm{Z} \mathrm{n}$ and $\mathrm{Sn}-0.7 \mathrm{Cu}-2.0 \mathrm{Sb}$ solders respectively; the deformation mechanism is dislocation climb controlled by the lattice diffusion for all solders.

Arab J. Nucl. Sci. \& Applic. Vol. 52, No. 3 (2019) 


\section{References}

1. G. Zeng, S. Xue, L. Gao, L. Zhang, Y. Hu and Z. Lai, "Interfacial microstructure and properties of $\mathrm{Sn}-0.7 \mathrm{Cu}-0.05 \mathrm{Ni} / \mathrm{Cu}$ solder joint with rare earth $\mathrm{Nd}$ addition", J. Alloy Compd., 509, (2011), 7152-61.

2. Yu Chi - Yang, Wei - Yu Chen and Jeng.Gong Duh, "Suppressing the growth of $\mathrm{Cu}-\mathrm{Sn}$ intermetallic compounds in $\mathrm{Ni} / \mathrm{Sn}-\mathrm{Ag}-\mathrm{Cu} / \mathrm{Cu}-$ $\mathrm{Zn}$ solder joints during thermal aging", Intermetallics, 26, (2012), 11-17.

3. M.L. Huang, C.M.L. WU and L. Wang, "Creep Resistance of Tin-Based Lead - Free Solder Alloys", Journal of Electronic Materials, 34, 11, (2005), 1373-1377.

4. C.M.L. Wu and M.L. Huang, "Creep Behavior of Eutectic Sn-Cu Lead- Free Solder Alloy", J. Electronic Materials, 31, 5, (2002), 442 - 448.

5. T. Ventura, S. Terzi, M. Rappaz and A.K. Dahle "Effects of solidification kinetics on microstructure formation in binary $\mathrm{Sn}-\mathrm{Cu}$ solder alloys", Acta Mater., 59 (4), (2011), 1651-1658.

6. A.F. Abd El-Rehim and H.Y. Zahran, "Microstructure evolution and mechanical properties of $\mathrm{Sn} 0.7 \mathrm{Cu} 0.7 \mathrm{Bi}$ lead-free solders produced by directional solidification", Journal of Alloys and Compounds, 295, (2017), 36663673.

7. M. Kamal and T. El-Ashram, "Micro-creep of rapidly solidified $\mathrm{Sn}-0.7 \mathrm{wt} \% \mathrm{Cu}-\mathrm{In}$ solder alloys", Mater. Sci. Eng., A, 456, (2007), 1- 4.

8. C.M.L. Wu, D.Q. YU, C.M.T. Law, and L. Wang, "Microstructure and Mechanical Properties of New Lead-Free $\mathrm{Sn}-\mathrm{Cu}-\mathrm{RE}$ Solder Alloys", Journal of Electronic Materials, 31, 9, (2002), 928-932.

9. G. Li, Y. Shi, H. Hao, Z. Xia, Y. Lei and F. Guo, "Effect of phosphorus element on the comprehensive properties of $\mathrm{Sn}-\mathrm{Cu}$ lead-free solder", Journal of Alloys and Compounds, 491, (2010), 382-385.

10. A.A. El-Daly and A.E. Hammad, "Enhancement of Creep Resistance and Thermal Behavior of Eutectic Sn-Cu Lead Free Solder Alloy by Ag and In-Additions", Materials and Design 40, (2012), 292-298.

11. A.A. El-Daly and A.E. Hammad, "Development of high strength $\mathrm{Sn}-0.7 \mathrm{Cu}$ Solders with the addition of small amount of $\mathrm{Ag}$ and In", J. of Alloys and Compounds, 509, (2011), 8554-8560.

12. S.I. Mudryi, I.I. Shtablavyi, V.I. Sklyarchuk, Y.O. Plevachuk, A.V. Korolyshyn and A.S. Yakymovych, "Structure and electric resistance of $\mathrm{Sn}-\mathrm{Cu}(\mathrm{Ag})$ solders in the pre- crystallization temperature range", Materials Science, 46, 4, (2011), 464-472.

13. S.N. Alam, Prerna Mishra and Rajnish Kumar "Effect of $\mathrm{Ag}$ on $\mathrm{Sn}-\mathrm{Cu}$ and $\mathrm{Sn}-\mathrm{Zn}$ lead free solders" Materials Science-Poland, 33(2), (2015), 317-330.

14. Guang Zeng, Songbai Xue and Liang Zhang, "Recent Advances on $\mathrm{Sn}-\mathrm{Cu}$ Solders with alloying elements", J Matter Sci, 22, (2011), 565-578.

15. Ning Zhao, M.L. Huang, Y. Zhong and H.T. $\mathrm{Ma}$, "Effects of rare earth $\mathrm{Ce}$ addition on the microstructure, wettability and interfacial reactions of eutectic $\mathrm{Sn}-0.7 \mathrm{Cu}$, J. Mater. Sci., 26(1), (2014), 345-352.

16. Gyenes, A. Simon, P. Lanszki, Z. Gacsi, "Effects of Nickel on the microstructure and the mechanical properties of $\mathrm{Sn}-0.7 \mathrm{Cu}$ leadfree solders", Archives of Metallurgy and Materials, 60, 2, (2015), 1449-1454.

17. Tarek -Ashram and R.M. Shalaby, "Effect of Rapid Solidification and Small Additions of $\mathrm{Zn}$ and $\mathrm{Bi}$ on the Structure and Properties of Sn$\mathrm{Cu}$ Eutectic Alloy", Journal of Electronic Materials, 34, 2, (2005), 212-215.

18. H.Y. Song, Q.S. Zhu, Z.G. Wang, J.K. Shang and M. Lu, "Effects of $\mathrm{Zn}$ addition on microstructure and tensile properties of $\mathrm{Sn}$ $1 \mathrm{Ag}-0.5 \mathrm{Cu}$ alloy", Materials Science and Engineering A, 527, (2010), 1343-1350.

19. K. Pietrzak, M. Grobelny, K. Makowska, N. Sobczak, D. Rudnik, A. Wojciechowski, and E. Sienicki, "Structural Aspects of the Behavior of Lead-Free Solder in the Corrosive Solution", Journal of Materials Engineering and Performance, 21, 5, (2012), 648-654.

20. M.T. Nawar, B.A. khalifa, G.S. Al-Ganainy, and A.W. Shalaby, "Crystallinity, crystallite size and some physical properties of two fiber maturity levels in some Egyptian cotton cultivars", Egypt. J. Sol., 18, (1), (1995) 61-73.

21. N. Barakat, B.A. Khalifa, F. Sharaf and A. ElBahy, "X-ray diffraction studies of $\mathrm{\gamma}$ irradiated Nylon 6 (Polycapramide) fibers", Egypt. J. Phys. 15, (2), (1984) 237-246.

22. Carina Morando, Osvaldo Fornaro, Olga Garbellini \& Hugo Palacio, "Thermal properties of Sn-based solder alloys", J Mater Sci: Mater Electron, 25, 8, (2014), 3440 -3447.

23. A.M. Yassin, R.L. Reuben, G. Saad, M.H.N. Beshai and S.K. Habib, "Effect of annealing and microstructure on the creep behavior of an Sn-10wt\%Sb alloy", Proc. Instn. Mech. Engrs., 213, (1999), 59-68.

24. B.A. Khalifa, R. Afify Ismail, A.M. Yassin, "Structure Analysis, Enhancement of Creep Resistance and Thermal Properties of Eutectic Sn-Ag Lead-Free Solder Alloy by $\mathrm{Ti}$ and $\mathrm{Cd}$ 
Additions", Journal of Advances Physics, 1, 8, (2017), 5092-5099.

25. A.A. El-Daly, H. El-Hosainy, T.A. Elmosalami, W.M. Desoky, "Micro-structural modifications and properties of low-Agcontent $\mathrm{SnAgCu}$ solder joints induced by $\mathrm{Zn}$ alloying", Journal of Alloys and Compounds, 653, (2015), 402-410.

26. Yujin Park, Jung-Hwan Bang, Chul Min Oh, Won Sik Hong and Namhyun Kang, "The Effect of Eutectic Structure on the Creep Properties of $\mathrm{Sn}-3.0 \mathrm{Ag}-0.5 \mathrm{Cu}$ and $\mathrm{Sn}-8.0 \mathrm{Sb}$ 3.0Ag Solders", Metals, 7, (2017), 540.

27. J. Friedel, "Dislocations", (Pergamon Press, London, 1964); M.T. Mostafa, Phys. Status Solidi, A 163, (1997), 39-44.

28. J.H. Lau, Ed., Thermal Stress and Strain in Microelectronics Packaging, van Nostrand Reinhold, New York, chapter 7, "Die Stress Measurement Using Piezoresistive Stress Sensors", by J. N. Sweet, (1993), pp. 221.

29. J.E. Bird, A. K. Mukherjee and J.E. Dorn, "Quantitative relation between properties and microstructure", (Israel University Press, (1969, 255-261.

30. A.A. El-Daly, Y. Swilem, AE. Hammad, "Creep properties of $\mathrm{Sn}-\mathrm{Sb}$ based lead free solder alloys", J. Alloys Compd., 471, 471, (2009), 98-104. 